\title{
Looking Ahead: Part III
}

\author{
Gian Italo Bischi ${ }^{1}$ and Michael $\operatorname{Kopel}^{2(凶)}$ \\ 1 DESP-Department of Economics, Society, Politics, University of Urbino Carlo Bo, \\ 42 Via Saffi, 61029 Urbino, PU, Italy \\ gian.bischi@uniurb.it \\ 2 Institute of Organization and Economics of Institutions, University of Graz, \\ Universitätsstrasse 15/E4, Graz, Austria \\ michael.kopel@uni-graz.at
}

\begin{abstract}
In the past decades, manufacturing firms have increasingly off-shored main activities along their value chain to emerging economies in order to take advantage of lower costs. More recently, however, the trend of re-shoring has gained increasing attention. We argue that more research is needed to fully understand firms' motives for bringing their activities back home. Furthermore, multinational firms need to evaluate their activities along environmental, social and governance dimensions. Research on corporate social responsibility strategies of multinational enterprises and their global value chains is still scarce, however.
\end{abstract}

Keywords: Off-shoring $\cdot$ Re-shoring $\cdot$ Corporate social responsibility

\section{Conclusions and Future Challenges}

For the European Union (EU), the uneven geographical distribution of economic activity among and even within member countries is a huge challenge. These spatial inequalities evolve over time and follow complex patterns which are influenced by economic, geographic, institutional and social factors. The main question that arises is "What are the drivers for such empirically observed heterogeneity of economic activity?" Clustering might take place for a variety of reasons, such as to be closer to large markets, to exploit scale economies and knowledge spillovers, and to benefit from lower transportation costs. Institutions at different territorial levels (e.g. at the EU, national, regional or local level) obviously have a strong impact as they set the regulatory framework that guides the decisions of economic actors and, thereby, foster growth and reduce regional disparities. Consequently, it is important to increase the quality of governance and to develop a better understanding of the linkages and the coordination issues between central and local governments.

The European market offers a wide array of examples of geographic areas where groups of firms are interconnected by horizontal and vertical relations and locate and interact. The International Business literature groups the drivers for location decisions into two broad categories (e.g. Alcácer et al. 2013). First, endowment drivers include location traits such as physical infrastructure, labor

(C) The Author(s) 2018

P. Commendatore et al. (eds.), The Economy as a Complex Spatial System,

Springer Proceedings in Complexity, DOI 10.1007/978-3-319-65627-4_12 
force quality, cultural distance, and institutional features like political risk and the enforcement of property rights. Second, agglomeration drivers include interfirm technological spillovers and access to specialized labor and specialized intermediate inputs. In addition to these two established categories, McIvor (2013) argues more recently that an analysis based on the Transaction Cost approach and the Capability perspective can contribute to an improved understanding of what drives firms' location activities. Finally, a growing stream of papers has demonstrated that the behavior of MNEs - which are typically active in oligopolistic markets - is crucially influenced by strategic interaction with various stakeholders like rival firms, input suppliers, and regulators (e.g. Kopel et al. 2015; Head et al. 2002; Leahy and Pavelin 2008; Leahy and Montagna 2009; Alcácer et al. 2013, 2015; Sanna-Randaccio and Veugelers 2007; Belderbos et al. 2008; Wu and Zhang 2014).

The objective of the working group on social and industrial interactions was to improve our understanding of the emergence of (behavioral) heterogeneity in the European Union by looking at the EU as a complex, multi-level, evolving geographical system and by taking into account the dynamic processes that occur within such a system. The main focus of the working group was on the role of economic agents at the micro-level (e.g. firms, suppliers, consumers) in spatial economic systems. In particular, multinational enterprises (MNEs) frequently have to make vital decisions concerning the geographic location of activities along their value chain such as retail, production, research \& development $(\mathrm{R} \& \mathrm{D})$, distribution, and services. These location choices of firms interact with and are crucially influenced by their market, social, and institutional environment. Hence, emphasis was also given to the development of improved strategies for EU regional policies. The majority of research carried out by the working group on social and industrial interactions is representative of the game-theoretic approach. Hence, the common element is the assumption that players in the game (e.g. firms, suppliers, regulators) are taking into account that they are interacting with rational players and, hence, that all players are reacting strategically to the choices taken by the other players. From the work that has been done by this group of researchers over the last years, several open issues have been identified that are promising for future research activities. We expect that pursuing these topics will improve our knowledge about the drivers of homogeneity or heterogeneity of firms' (location) choices.

With regard to future research, we notice that the dynamics of firms' strategies are evident. Trade liberalization and innovations in information and communication technologies have provided incentives for MNEs to move their production abroad in order to exploit cost advantages. These off-shoring and outsourcing activities were oftentimes solely based on the lower cost of labor in foreign developing countries. However, more recently firms are reconsidering their previous decisions and are starting to 're-shore' or 'near-shore' their activities (Ellram 2013; Porter and Rivkin 2012). Accounting for the hidden costs of outsourcing and off-shoring, three reasons are advanced for explaining this trend (e.g. Booth 2013; Barbieri and Stentoft 2016; Stentoft et al. 2016; de Treville 
and Trigeorgis 2010). First, the labor cost advantage of foreign locations in developing countries has been significantly reduced and the costs of transportation are rising sharply. Instead of cheap labor, multinationals are now considering direct investments abroad to take an advantageous position in conquering fast growing foreign markets like China. Second, firms are realizing that keeping activities like manufacturing and $\mathrm{R} \& \mathrm{D}$ at distant locations can have negative consequences on innovation and quality since knowledge spillovers are localized. Moreover, large distances disproportionately increase the risk of supply chain disruptions. Given such a globalized channel structure, firms might damage their reputation as they are increasingly held responsible if their foreign suppliers disregard national codes of conduct or norms. Third and finally, companies are starting to re-shore to be able to customize their products to preferences in local markets and to be able to respond to customs and preferences quickly. Although some work on strategic re-location and near-shoring decisions of multinational firms has been done, we believe that more research is needed to understand the strategic motives of MNEs for choosing particular channel structures and locations.

Location decisions and the choice of channel structures and their interaction with the Corporate Social Responsibility (CSR) strategies of multinational enterprises also deserve more attention. According to Kitzmüller and Shimshack (2012), the field of international trade and CSR policies is still under-researched. With the introduction of Directive 2014/95/EU on the disclosure of non-financial and diversity information, the European Commission expressed its view on CSR as an extended corporate governance policy. The Directive introduces enhanced reporting requirements on environmental, social, and governance (ESG) issues. It affects not only corporate reporting, but also measurement of performance on ESG dimensions. As a consequence, it is expected to have an impact on internal firm processes, compensation issues, and incentives of top management. Relating to the reputation loss of manufacturers mentioned above, if their suppliers do not meet CSR standards the question arises how MNEs can control their global supply chains and ensure compliance of their partners. Additionally, an MNE's mode of entry into a foreign country might crucially interact with its investments in corporate social responsibility (see, e.g., Manasakis et al. 2017). During the process of the development of Directive 2014/95/EU, concerns were raised that due to this new regulation European firms will have a competitive disadvantage against their international rivals. An important issue is, therefore, if CSR enhances or diminishes the competitiveness of European firms against their international rivals. Furthermore, the question might be raised whether investments in CSR threaten the long run survival of MNEs and lead to the dominance of firms that only narrowly seek to achieve profits. Again, some preliminary work on the impact of social and environmental objectives in oligopolistic markets has been done, but we need more research to fully understand the conditions that make it possible for firms to consider non-profit objectives and still do well. Taken together, the brief review hopefully demonstrates that there are ample research opportunities that might lead to novel insights on the drivers that motivate multinational firms' decisions under competition and strategic interaction. 


\section{References}

Alcácer, J., Dezsö, C.L., Zhao, M.: Firm rivalry, knowledge accumulation, and MNE location choices. J. Int. Bus. Stud. 44, 504-520 (2013)

Alcácer, J., Dezsö, C.L., Zhao, M.: Location choices under strategic interactions. Strateg. Manag. J. 36, 197-215 (2015)

Barbieri, P., Stentoft, J.: Guest editorial, special issue on 'Reshoring: a supply chain innovation perspective'. Oper. Manag. Res. 9(3), 49-52 (2016)

Belderbos, R., Lykogianni, E., Veugelers, R.: Strategic R\&D location by multinational firms: spillovers, technology sourcing, and competition. J. Econ. Manag. Strategy 17(3), 759-779 (2008)

Booth, T.: Here, there and everywhere. In: The Economist, Special Report: Outsourcing and Offshoring, 19 January 2013

de Treville, S., Trigeorgis, L.: It may be cheaper to manufacture at home. Harvard Bus. Rev. 88(10), 84-87 (2010)

Ellram, L.M.: Offshoring, reshoring and the manufacturing location decision. J. Supply Chain Manag. 49(2), 3-5 (2013)

Head, K., Mayer, T., Ries, J.: Revisiting oligopolistic reaction: are decisions on Foreign direct investment strategic complements? J. Econ. Manag. Strategy 11(3), 453-472 (2002)

Kitzmueller, M., Shimshack, J.: Economic perspectives on corporate social responsibility. J. Econ. Lit. 50(1), 51-84 (2012)

Kopel, M., Pezzino, M., Brand, B.: Strategic location choice, R\&D, and sourcing strategie's. In: Commendatore, P., Kayam, S., Kubin, I. (eds.) Complexity and Geographical Economics. Topics and Tools. Springer Book Series on Dynamic Modeling and Econometrics in Economics and Finance (2015)

Leahy, D., Pavelin, S.: Playing away to win at home. J. Econ. Bus. 60(5), 455-468 (2008)

Leahy, D., Montagna, C.: Outsourcing vs. FDI in oligopoly equilibrium. Spat. Econ. Anal. 4(2), 149-166 (2009)

Manasakis, C., Mitrokostas, E., Petrakis, E.: Strategic Corporate Social Responsibility by a Multinational Firm, Discussion Paper No. 246, Düsseldorf Institute for Competition Economics (2017)

McIvor, R.: Understanding the manufacturing location decision: the case for the transaction cost and capability perspectives. J. Supply Chain Manag. 49(2), 23-25 (2013)

Porter, M., Rivkin, R.W.: Choosing the United States. Harvard Bus. Rev. 90(10), 80-93 (2012)

Sanna-Randaccio, F., Veugelers, R.: Multinational knowledge spillovers with decentralised R\&D: a game-theoretic approach. J. Int. Bus. Stud. 38, 47-63 (2007)

Stentoft, J., Olhager, J., Heikkilä, J., Thomas, L.: Manufacturing backshoring: a systematic literature review. Oper. Manag. Res. 9(3), 53-61 (2016)

$\mathrm{Wu}, \mathrm{X}$., Zhang, F.: Home or overseas? An analysis of sourcing strategies under competition. Manag. Sci. 60(5), 1223-1240 (2014) 
Open Access This chapter is licensed under the terms of the Creative Commons Attribution 4.0 International License (http://creativecommons.org/licenses/by/4.0/), which permits use, sharing, adaptation, distribution and reproduction in any medium or format, as long as you give appropriate credit to the original author(s) and the source, provide a link to the Creative Commons license and indicate if changes were made.

The images or other third party material in this chapter are included in the chapter's Creative Commons license, unless indicated otherwise in a credit line to the material. If material is not included in the chapter's Creative Commons license and your intended use is not permitted by statutory regulation or exceeds the permitted use, you will need to obtain permission directly from the copyright holder.

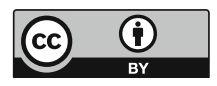

